\title{
Ecological Impacts of Oil-Palm Plantation on Butterfly and Bird Species Diversity
}

\author{
Rozza Tri Kwatrina ${ }^{1}$, Yanto Santosa ${ }^{2}$, M. Bismark ${ }^{3}$, Nyoto Santoso ${ }^{2}$ \\ ${ }^{1}$ Graduate Program of Tropical Biodiversity and Conservation, Faculty of Forestry, Bogor Agricultural University, Dramaga \\ Campus, Bogor, West Java, Indonesia 16680 \\ ${ }^{2}$ Department of Forest Resource Conservation and Ecotourism, Faculty of Forestry, Bogor Agricultural University, Dramaga \\ Campus, Bogor, West Java, Indonesia 16680 \\ ${ }^{3}$ Center of Forestry Research and Development, Forestry Research Development and Innovation Agency, Ministry of Natural \\ Environment and Forestry, Jl. Gunung Batu No. 5, Bogor, West Java, Indonesia 16680
}

Received December 28, 2017/Accepted April 18, 2018

\begin{abstract}
The expansion of oil-palm plantations in Indonesia is often blamed as the driving causes of deforestation and impacts on environmental changes including the destructed biodiversity. Our understanding regarding environmental impacts on biodiversity is still limited. We address this issue by examining the diversity of butterfly and bird species under two type habitat conditions in Central Borneo. We calculated the butterfly and bird species number, richness, evenness, similarity, and composition inside the established oil-plantation area comprising four large-scale plantations and seven smallholding plantations, as habitat after plantation establishment. In comparison, we did so similarly inside secondary forest and shrubs, as habitat before oil-palm plantation establishment. Our results revealed that the habitat after plantation establishment exhibited a higher number of butterfly and bird species than the habitat beforehand. However, the richness, evenness, and similarity indices for the species revealed variations, which were affected by dominant species in two habitats. The establishment of oil-palm plantation brought about significant impacts on the composition of species and affected the species similarities between two habitats. The oilpalm plantation landscape and reserved forest vegetation were essential in supporting diversity and ecological role of species on habitat condition after oil-palm plantation establishment.
\end{abstract}

Keywords: oil palm plantation, avifauna, Lepidoptera, high conservation value, Borneo

*Correspondence author,email:rozzatk@yahoo.com

\section{Introduction}

The challenges of forest management in the tropics as a center of biodiversity is balancing the environmental conservation with utilization for agriculture. Globally, the expansion and intensification of agriculture and plantations are considered the greatest threat to biodiversity (Fizherbert et al. 2008). Therefore, as an agrarian country that relies its development income on agriculture and plantation sectors, Indonesia have to manage the landscape of forests and land by optimizing the natural resource use, concurrently ensuring the sustainability of biodiversity.

Oil palm (Elaeis guineensis) currently signifies as one of the valuable and dependable products for Indonesia's industries and economies. Since the last 10-year period, the oil-palm plantation has more developed and is predicted will reach 12.3 million ha in 2017 (Directorate General of Plantation 2017). Nowadays, the demand on Indonesia's palm was the highest in 2017, thereby placing Indonesia as one of the greatest palm-oil producing countries in the world (Infosawit 2017). The high economy value has encouraged the establishment and expands of the oil-palm plantation. Such oil-palm plantation establishment brings about changes in the land cover at the concession area administered by the estate companies and the plantation area owned by communities. Although those trend changes are legal, those trends keep prompting a strong accusation from several institutions regarding the impacts of oil-palm establishment on deforestation and environmental changes, including the biodiversity (Sawit Watch 2017).

Butterflies and birds could represent partially the biodiversity that affected by the conversions to the oil-palm plantation. In fact, butterflies provide a significant role in securing forest ecosystem as a herbivore, pollinators, host for the parasites, prey for the predators (Hammond \& Miller 1998; Dahelmi 2000; Atmowi et al. 2007). Such essential roles render the butterflies to be frequently used as the natural indicator of ecological changes, whereby the more varying the butterfly species, indicatively the better would be the environmental condition; and vice versa (Amir et al. 2003; Posha \& Sodhi 2006; Koh 2007). Birds also perform essential roles in the ecosystem, as pollinators, as an indicator of water-body quality, and predators. The presence of various bird species with their varying roles could indicate good ecological stability at a location.

Several research activities associated with butterflies and birds particularly at the oil-palm plantation site have been conducted at several locations in the world (Koh 2008; Koh \& Wilcove 2008; Edwards et al. 2013). Unfortunately, in 
Indonesia, the information about the impact of land changes or conversion to the oil-palm plantation on the biodiversity (e.g. butterflies and birds) is still insufficient and only performed in Riau region (Erniwati et al. 2016; Santosa et al. 2017; Santosa \& Purnamasari 2017). Nonetheless, such research results indicate a change in biodiversity caused by the establishment of the oil-palm plantation. However, the difference in environmental condition and characteristics of oil-palm plantation could bring about different ecology effect and impacts. Borneo that typifies as one of the biodiversity hotspots is the second largest area of the oil-palm plantation in Indonesia (28.83\%) (Directorate General of Plantation/Estate 2017). Therefore, this research was aimed to reveal the ecological impact of oil palm plantation establishment on butterflies and birds, especially in Borneo. About the negative accusation about the oil-palm issues, this research seems to be essential as a scientific confirmation on controversial several problems associated with the oil-palm plantation impacts on species biodiversity, particularly butterflies and birds. Concurrently, this study could be a beneficial consideration to the conservation of biodiversity in the oil-palm plantation.

\section{Methods}

Study site The study was conducted on four large-scale plantations i.e. PT. BGA (16,276.5 ha), PT. AMR $(7,448.56$ ha), PT. GSIP (6,979 ha), and PT. BLP (31,600 ha) and at seven smallholder plantations in Kotawaringin Barat Regency, Central Borneo Province (Figure 1). The two companies were located at Kumai Sub-district, while the others at Pangkalan Lada Sub-district.

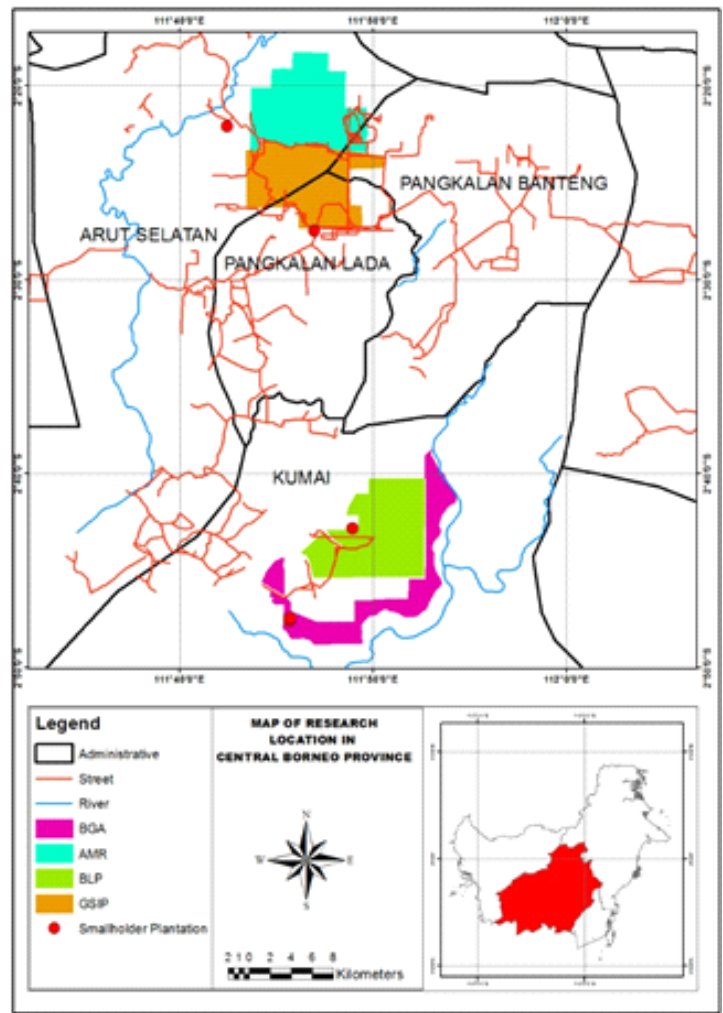

Figure 1 Research sites at study area in Central Borneo.
Data collection Data collection of butterflies and birds was conducted in August 2017. This study uses a modification of impact assessment approach according to Terlizzi et al. (2005) and Smiley et al. (2009). The study and data collection was conducted on two different habitat conditions, i.e. habitat conditions as before the establishment of oil palm plantations; and habitat conditions after oil palm plantations. Habitat conditions before the development of oil palm plantations are identified through lansat image analysis. Based on the results of the analysis, it is known that there are two types of land cover that dominate the research site before the establishment of plantations, namely secondary forest and shrubs. Both are then categorized as habitat conditions prior to oil palm development (BPE) as a control area. Habitat conditions after the establishment of oil palm plantations (APE) are sites in the oil palm plantation areas managed by companies and oil palm plantation areas owned by the community, as impacted area. Large-scale plantations consist of oil palm trees at various ages, consisting of young tree stands (varying from 1 to 5 years), medium-sized trees (11-19 years old), old tree stands (4-24 years old); and a reserved area for $\mathrm{HCV}$ (high conservation value) (Erniwati et al. 2016; Santosa etal.2016).

The composition of vegetation at shrub area, besides comprising mainly as shrub vegetation, there also grew other plants, such as gelam (Melaleuca leucadendron), kacangkacangan (Mucunan bracteata), and harendong (Melastoma malabathrium). In the secondary forest were present several Dipterocarpaceae's species, such as Shorea leprosula, $S$. pervifolia, Dipterocarpus comutus, and several mahang species (Macaranga spp.). The below vegetations at large scale plantation as well as smallholding plantation comprised of sintrong (Crassocephalum crepidiodes), pakis (Stenochlaena palustris), harendong (M. malabathricum), Paspalum conjugatum, Ottochloa nodosa, Eleusine indica, Ageratum conyzoides, and Clidemia hirta.

The collecting of butterflies data was conducted in a parallel way used the time-search method being a modification of line transect method $(1 \mathrm{~km})$, whereby the observation plots were not limited by particular distance or vastness, but by time (minutes) (Figure 2). The observation was conducted three times (further regarded as replicates), which took place in the morning (at 08:00-11:00 a.m. Indonesia's western time / IWT) when the air became rather warmer. The butterflies as object were caught using a netshaped trap and then put into a papilot paper. The caught butterflies were subsequently identified using the butterfly field guide. The acquired data were recorded on the tally sheet (Pascher et al. 2010).

Inventorying the biodiversity of bird species was also performed in a parallel way using the combination methods between the line transect and observation point. The transect path exhibited one-km length with 100-m width to the right and left per path. The observation was carried out in the morning (at 06:00-08:00 a.m. IWT) and in the afternoon $(15: 30-17: 30$ p.m. IWT) as many as three times (replications). The data covered the species encountered, number of individual birds as found, and birds sound. Also, the observation was conducted on the environment condition, such as plant species on the plantation floor, 


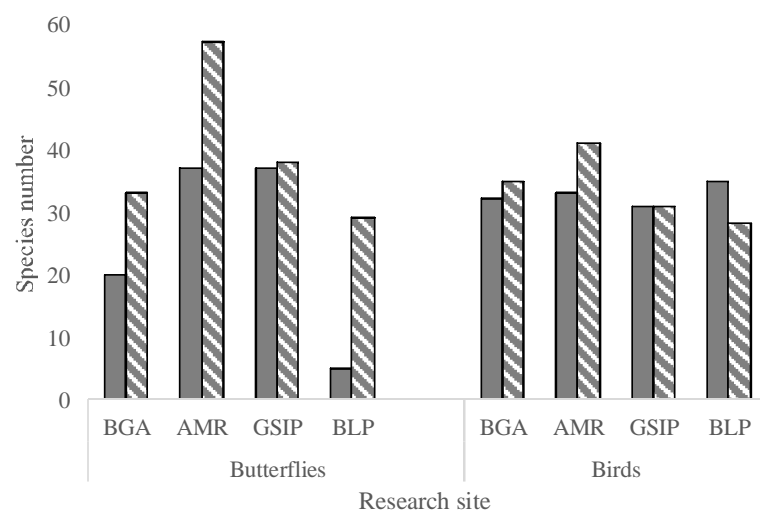

Figure 2 Number of butterfly and bird species before and after the establishment of the oil-palm plantation. BGA, AMR, GSIP, BLP (four particular observed location at the research location); $\square$ the location as before the establishment of oil-palm plantation (BPE); $\square$ the location after the establishment of oil-palm plantation (APE).

grasses/shrubs, and the forest nearby. The observation was performed with binoculars to assist the eyesight regarding the bird species. The acquired data and observed results were then recorded on the tally sheet.

Data analysis The impacts of oil-palm plantation on the diversity of butterflies and birds could be assessed and figured out by comparing the number of each of those two animal classes, richness of species, evenness of species, and composition of species at the habitat condition before and after the establishment of oil-palm plantation. The variation in species diversity was calculated using the species richness index formulated by Magurran (1988). Further, to determine the species evenness, we employed the evenness index, while the similarity of species community before the establishment of the oil-palm plantation and afterward was calculated using the Sorensen index. The formulae for those three indices were presented below as show in Equation [1]:

$$
\operatorname{Dmg}=\frac{(\mathrm{S}-1)}{\operatorname{Ln}(\mathrm{N})^{\prime}} \quad \mathrm{E}=\frac{\mathrm{H}^{\prime}}{\operatorname{Ln}(\mathrm{S})^{\prime}} \quad \mathrm{SI}=\frac{2 \times \mathrm{C}}{\mathrm{A}+\mathrm{B}^{\prime}}
$$

$\mathrm{H}=\sum \mathrm{H}^{\prime}=\sum p i . \operatorname{Ln} p i$

note: Dmg $=$ index of species richness, according to Margalef's formula; $\mathrm{E}=$ index of species evenness; $\mathrm{SI}=$ index of species similarity (Sorensen's formula); $\mathrm{S}=$ number of species (butterflies as well as birds); $\mathrm{N}=$ number of individuals for each species (butterflies as well as birds); $\mathrm{H}^{\prime}=$ index of species diversity; $\mathrm{C}=$ total number of species at those two habitats (before oil-palm plantation establishment and afterwards); $\mathrm{A}=$ number of species at the habitat condition before the establishment of oi-palm plantation; $\mathrm{B}=$ number of species at the habitat condition after the establishment of oil-palm plantation; $\mathrm{p} i=$ proportion of a species $i$ to all of the species.

\section{Results and Discussion}

Impacts on the number and diversity of species Research results revealed that changes or conversion of the land cover originally from shrubs and secondary forest to the oil-palm plantation brought about substantial changes in the number of butterfly and bird species. Concerning the butterflies, such impacts rendered the number of their species to increase at all the observed locations from formerly only 5-37 species to become 29-57 species or in a range corresponding to 2.7-480\% increase (Table 1). It was relatively similar to the figure obtained from the previous research results which were carried out at the area of oil-palm plantation in Riau, among others: Santosa et al. (2017) who found 30 butterfly species; Febrita et al. (2014) who found 60 species; and Santosa and Purnamasari (2017) who found 42 species. Likewise, the similar condition also occurred to the bird. For birds, at two locations there occurred an increase separately from consecutively 32 and 33 species to 35 and 41 species, respectively, or ranging at $9.37-24.24 \%$ increase, while at one location, on the contrary, no changes occurred; and at the other one location, there occurred a decrease (from 35 to 28 species, or precisely $20 \%$ decrease) (Figure 2 ). The decrease in the number of bird species at BLP location could occur, as the secondary forest that previously existed before the establishment of the oil-palm plantation had contributed quite enormously and favorably to the number of bird species compared to the condition of their habitat after the presence of such plantation. Compared to the research results by Erniwati et al. (2016), who found 43 bird species at the oilpalm plantation in Riau, then the number as obtained in these research results (28-41 species) (Table 2) was not so different.

Observation results also revealed that there occurred notable changes in species diversity/richness. The butterfly richness turned out to be increasing at three particular locations (BGA, AMR, and BLP) (Figure 3). Meanwhile, at one location (GSIP) the richness of butterflies sustained the decrease as much as $4.7 \%$ of their previous diversity, which seemed due to the dominant presence of Ypthima baldus horsfieldi species. On the contrary for birds, the decrease in diversity took place at two locations (BGA and BLP), which was strongly attributed to the domination by Pycnonotus goiavier, while at consecutively GSIP and AMR locations there occurred a richness increase as much as $0.17 \%$ and $0.29 \%$, respectively (Figure 3 ). The diversity of bird and butterfly in APE habitat conditions also show the variations. The values of the species diversity were increased respectively by $2.86-86.26 \%$ in butterflies, and $7.84-8.33 \%$ in birds, whereas declining values ranged from $0.57-7.17 \%$ in butterflies, and $0.94-11.61 \%$ in birds (Figure 4). The diversity of bird and butterfly in APE habitat conditions also show the variations. The values of the species diversity were increased respectively by $2.86-86.26 \%$ in butterflies, and $7.84-8.33 \%$ in birds, whereas declining values ranged from $0.57-7.17 \%$ in butterflies, and $0.94-11.61 \%$ in birds (Figure 4). The index of richness and index of diversity take into calculation the number of species and also the number of individuals in the entire species. Accordingly, large or small number of individuals for particular species could affect the value of such index. 
Table 1 Composition of butterfly species before (BPE) and after (APE) the establishment of the oil-palm plantation at the research location (BGA, AMR, GSIP, BLP)

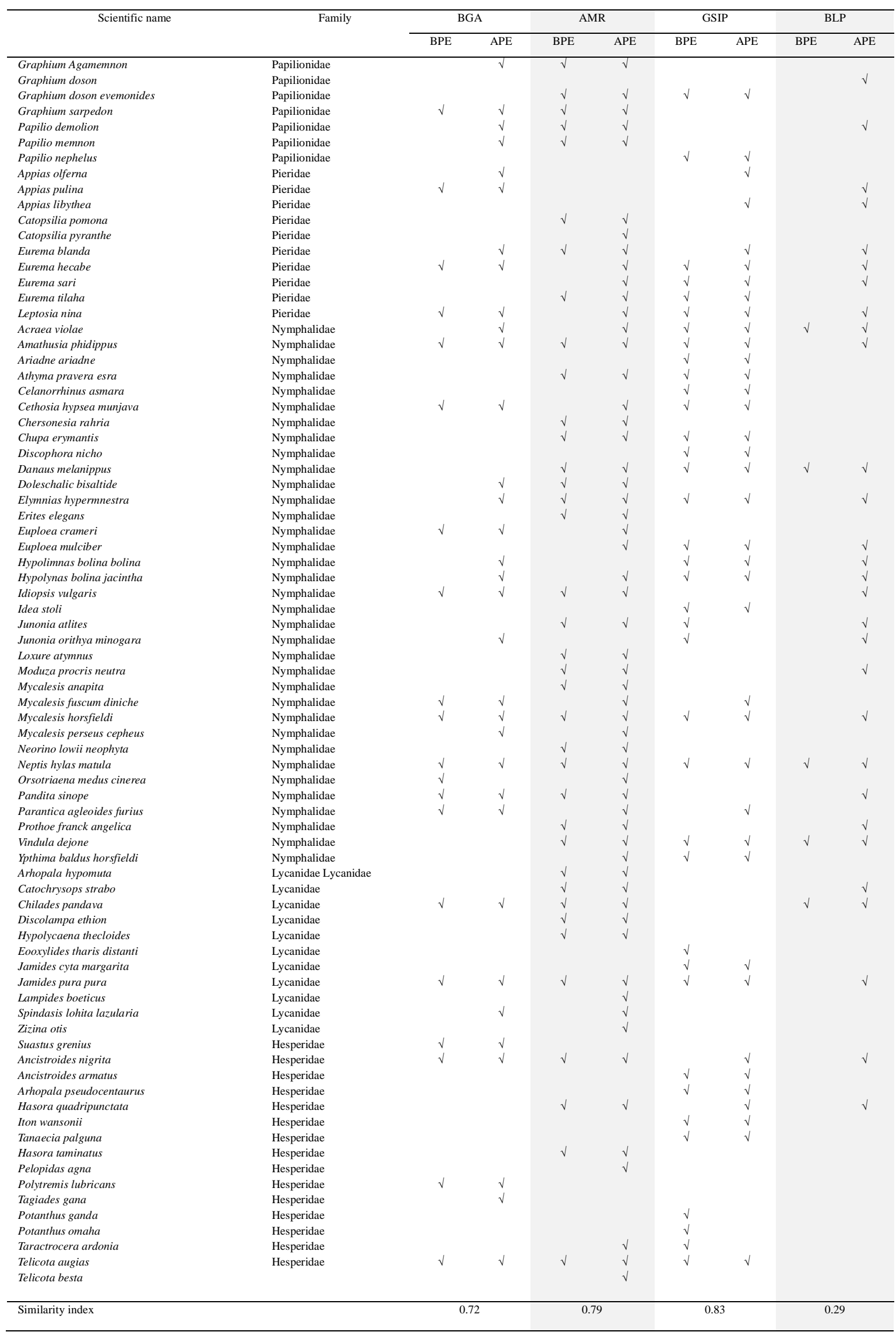


Table 2 Composition of birds species before (BPE) and after (APE) the establishment of the oil-palm plantation at the research location (BGA, AMR, GSIP, BLP)

\begin{tabular}{|c|c|c|c|c|c|c|c|c|c|}
\hline \multirow[t]{2}{*}{ Scientific name } & \multirow[t]{2}{*}{ Family } & \multicolumn{2}{|c|}{ BGA } & \multicolumn{2}{|c|}{ AMR } & \multicolumn{2}{|c|}{ GSIP } & & \\
\hline & & BPE & APE & BPE & APE & BPE & APE & BPE & $\mathrm{APE}$ \\
\hline Anthus novaeseelandiae & Motacillidae & & $\sqrt{ }$ & & & $\sqrt{ }$ & & & \\
\hline Ciconia stormi & Ciconiidae & $\sqrt{ }$ & & & & & & & \\
\hline Leptoptilos javanicus & Ciconiidae & $\sqrt{ }$ & & & & & & & \\
\hline Psittacula alexandri & Psittacidae & & & & $\sqrt{ }$ & & & & \\
\hline Psittacula longicauda & Psittacidae & $\sqrt{ }$ & $\sqrt{ }$ & $\checkmark$ & $\sqrt{ }$ & $\sqrt{ }$ & $\sqrt{ }$ & $\sqrt{ }$ & $\sqrt{ }$ \\
\hline Loriculus galgulus & Psittacidae & $\sqrt{ }$ & $\sqrt{ }$ & & & & & $\sqrt{ }$ & \\
\hline Microhierax fringillarius & Falconidae & $\sqrt{ }$ & $\sqrt{ }$ & $\sqrt{ }$ & $\sqrt{ }$ & & & & \\
\hline Ixobruchus cinnamomeus & Ardeidae & & $\sqrt{ }$ & $\sqrt{ }$ & $\sqrt{ }$ & & & & $\sqrt{ }$ \\
\hline Butorides striata & Ardeidae & & & & & & & $\sqrt{ }$ & \\
\hline Ardea cinerea & Ardeidae & & & & & & & & $\sqrt{ }$ \\
\hline Lanius schach & Laniidae & $\sqrt{ }$ & $\sqrt{ }$ & & $\sqrt{ }$ & $\sqrt{ }$ & $\sqrt{ }$ & $\sqrt{ }$ & $\sqrt{ }$ \\
\hline Lonchura fuscans & Estrildidae & & $\sqrt{ }$ & $\sqrt{ }$ & $\sqrt{ }$ & $\sqrt{ }$ & $\checkmark$ & & $\sqrt{ }$ \\
\hline Centropus bengalensis & Cuculidae & & $\sqrt{ }$ & & $\sqrt{ }$ & $\sqrt{ }$ & $\checkmark$ & & $\sqrt{ }$ \\
\hline Centropus sinensis & Cuculidae & & $\sqrt{ }$ & $\sqrt{ }$ & $\sqrt{ }$ & & $\sqrt{ }$ & & $\sqrt{ }$ \\
\hline Cacomantis merulinus & Cuculidae & & & & $\sqrt{ }$ & & $\sqrt{ }$ & $\sqrt{ }$ & $\sqrt{ }$ \\
\hline Cuculus saturatus & Cuculidae & & & & & & & & $\sqrt{ }$ \\
\hline Chrysococcyx minutillus & Cuculidae & & & & & & & $\sqrt{ }$ & \\
\hline Anthreptes simplex & Nectariniidae & & & & & & & & $\sqrt{ }$ \\
\hline Nectarinia jugularis & Nectariniidae & & & & $\sqrt{ }$ & & & & \\
\hline Aethopyga siparaja & Nectariniidae & & & $\sqrt{ }$ & $\sqrt{ }$ & $\sqrt{ }$ & $\sqrt{ }$ & $\sqrt{ }$ & $\sqrt{ }$ \\
\hline Anthreptes singalensis & Nectariniidae & & & & & $\sqrt{ }$ & $\sqrt{ }$ & $\sqrt{ }$ & \\
\hline Anthreptes malacensis & Nectariniidae & & & & & $\sqrt{ }$ & $\sqrt{ }$ & & $\sqrt{ }$ \\
\hline Leptocoma sperata & Nectariniidae & & & & & $\sqrt{ }$ & $\sqrt{ }$ & $\sqrt{ }$ & \\
\hline Arachnothera longirostra & Nectariniidae & $\sqrt{ }$ & $\sqrt{ }$ & & & & & $\sqrt{ }$ & \\
\hline Passer montanus & Ploceidae & & & & & $\sqrt{ }$ & & & \\
\hline Dicaeum trigonostigma & Dicaeidae & & & $\sqrt{ }$ & $\sqrt{ }$ & $\sqrt{ }$ & $\sqrt{ }$ & $\sqrt{ }$ & \\
\hline Dicaeum concolor & Dicaeidae & & & & & $\sqrt{ }$ & $\sqrt{ }$ & & \\
\hline Prionochilus percussus & Dicaeidae & & & & & $\sqrt{ }$ & $\sqrt{ }$ & $\sqrt{ }$ & \\
\hline Rhamphococcyx curvirostris & Dicaeidae & $\sqrt{ }$ & $\sqrt{ }$ & & & $\sqrt{ }$ & $\sqrt{ }$ & & \\
\hline Caprimulgus affinis & Caprimulgidae & $\sqrt{ }$ & $\sqrt{ }$ & & $\sqrt{ }$ & $\sqrt{ }$ & & $\sqrt{ }$ & $\sqrt{ }$ \\
\hline Eurostopodus argus & Caprimulgidae & $\sqrt{ }$ & $\sqrt{ }$ & $\sqrt{ }$ & $\sqrt{ }$ & & & & \\
\hline Halcyon smyrnensis & Alcedinidae & $\sqrt{ }$ & & $\sqrt{ }$ & $\sqrt{ }$ & & & & $\sqrt{ }$ \\
\hline Halcyon chloris & Alcedinidae & & & & & & & & $\sqrt{ }$ \\
\hline Pelargopsis capensis & Alcedinidae & & & $\sqrt{ }$ & $\sqrt{ }$ & & & & \\
\hline Alcedo meninting & Alcedinidae & & & $\sqrt{ }$ & $\sqrt{ }$ & $\sqrt{ }$ & $\sqrt{ }$ & $\sqrt{ }$ & $\sqrt{ }$ \\
\hline Orthotomus sericeus & Sylviidae & $\sqrt{ }$ & $\sqrt{ }$ & $\sqrt{ }$ & $\sqrt{ }$ & $\sqrt{ }$ & $\sqrt{ }$ & $\sqrt{ }$ & $\sqrt{ }$ \\
\hline Orthotomus ruficeps & Sylviidae & & $\sqrt{ }$ & & $\sqrt{ }$ & & $\sqrt{ }$ & $\sqrt{ }$ & $\sqrt{ }$ \\
\hline Prinia flaviventris & Sylviidae & $\sqrt{ }$ & $\sqrt{ }$ & & & & & $\sqrt{ }$ & $\sqrt{ }$ \\
\hline Chloropsis sonnerati & Chloropseidae & & & & & & & $\sqrt{ }$ & \\
\hline Aegithina viridissima & Aeghitinidae & & & & & & & $\sqrt{ }$ & \\
\hline Macronous gularis & Timaliidae & $\sqrt{ }$ & $\sqrt{ }$ & $\sqrt{ }$ & $\sqrt{ }$ & $\sqrt{ }$ & $\sqrt{ }$ & $\sqrt{ }$ & \\
\hline Stachyris erythroptera & Timaliidae & & & $\sqrt{ }$ & $\sqrt{ }$ & $\sqrt{ }$ & $\sqrt{ }$ & $\sqrt{ }$ & \\
\hline Ducula aenea & Columbidae & $\sqrt{ }$ & $\sqrt{ }$ & $\sqrt{ }$ & $\sqrt{ }$ & & & $\sqrt{ }$ & $\sqrt{ }$ \\
\hline Treron curvirostra & Columbidae & $\sqrt{ }$ & $\sqrt{ }$ & $\sqrt{ }$ & $\sqrt{ }$ & $\sqrt{ }$ & $\sqrt{ }$ & & $\sqrt{ }$ \\
\hline Chalcophaps indica & Columbidae & & & & & & $\sqrt{ }$ & $\sqrt{ }$ & \\
\hline Streptopelia chinensis & Columbidae & $\sqrt{ }$ & $\sqrt{ }$ & & $\sqrt{ }$ & $\sqrt{ }$ & $\sqrt{ }$ & $\sqrt{ }$ & $\sqrt{ }$ \\
\hline Ichthyophaga ichthyaetus & Accipitridae & & & & & & & & $\sqrt{ }$ \\
\hline Elanus caeruleus & Accipitridae & & $\sqrt{ }$ & $\sqrt{ }$ & $\sqrt{ }$ & $\sqrt{ }$ & & & \\
\hline Spilornis cheela & Accipitridae & $\sqrt{ }$ & $\sqrt{ }$ & $\sqrt{ }$ & $\sqrt{ }$ & & & $\sqrt{ }$ & \\
\hline Corvus enca & Corvidae & $\sqrt{ }$ & $\sqrt{ }$ & $\sqrt{ }$ & $\sqrt{ }$ & $\sqrt{ }$ & $\sqrt{ }$ & & \\
\hline Hemipus hirundinaceus & Campephagidae & $\sqrt{ }$ & $\sqrt{ }$ & & & & & $\sqrt{ }$ & \\
\hline Pericrocotus igneus & Campephagidae & $\sqrt{ }$ & $\sqrt{ }$ & & & & & & \\
\hline Hypothymis azurea & Monarchidae & & & & & $\sqrt{ }$ & $\sqrt{ }$ & & \\
\hline Merops viridis & Meropidae & $\sqrt{ }$ & $\sqrt{ }$ & & & $\sqrt{ }$ & $\sqrt{ }$ & $\sqrt{ }$ & $\sqrt{ }$ \\
\hline Amaurornis phoenicurus & Rallidae & $\sqrt{ }$ & $\sqrt{ }$ & $\sqrt{ }$ & $\sqrt{ }$ & $\sqrt{ }$ & $\sqrt{ }$ & & $\sqrt{ }$ \\
\hline Gallinula chloropus & Rallidae & & & & & $\sqrt{ }$ & $\sqrt{ }$ & & \\
\hline Anthracoceros albirostris & Bucerotidae & $\sqrt{ }$ & $\sqrt{ }$ & $\sqrt{ }$ & $\sqrt{ }$ & & & $\sqrt{ }$ & \\
\hline Anthracoceros malayanus & Bucerotidae & & & & & & & $\sqrt{ }$ & \\
\hline Pachycephala grisola & Pachycephalidae & & & & & & & $\sqrt{ }$ & \\
\hline Gracula religiosa & Sturnidae & $\sqrt{ }$ & $\sqrt{ }$ & $\sqrt{ }$ & $\sqrt{ }$ & & & & \\
\hline Acridotheres javanicus & Sturnidae & & & $\sqrt{ }$ & $\sqrt{ }$ & $\sqrt{ }$ & & & \\
\hline Artamus leucorhyncus & Artamidae & $\sqrt{ }$ & & & & & & & \\
\hline Rhipidura javanica & Rhipiduridae & $\sqrt{ }$ & $\sqrt{ }$ & & $\sqrt{ }$ & & $\sqrt{ }$ & $\sqrt{ }$ & $\sqrt{ }$ \\
\hline Hirundo tahitica & Hirundinidae & & & $\sqrt{ }$ & $\sqrt{ }$ & & & & \\
\hline Pycnonotus plumosus & Pycnonotidae & $\sqrt{ }$ & $\sqrt{ }$ & $\sqrt{ }$ & $\sqrt{ }$ & & $\sqrt{ }$ & $\sqrt{ }$ & \\
\hline Pycnonotus goiavier & Pycnonotidae & $\sqrt{ }$ & $\sqrt{ }$ & $\sqrt{ }$ & $\sqrt{ }$ & $\sqrt{ }$ & $\sqrt{ }$ & $\sqrt{ }$ & $\sqrt{ }$ \\
\hline Pycnonotus bruneus & Pycnonotidae & & & $\sqrt{ }$ & $\sqrt{ }$ & & & $\sqrt{ }$ & \\
\hline Pycnonotus atriceps & Pycnonotidae & & & $\sqrt{ }$ & $\sqrt{ }$ & & & & \\
\hline Pycnonotus aurigaster & Pycnonotidae & $\sqrt{ }$ & $\sqrt{ }$ & $\sqrt{ }$ & $\sqrt{ }$ & $\sqrt{ }$ & $\sqrt{ }$ & & $\sqrt{ }$ \\
\hline Picus miniaceus & Picidae & & & $\sqrt{ }$ & $\sqrt{ }$ & & & & \\
\hline Micropternus brachyurus & Picidae & $\sqrt{ }$ & $\sqrt{ }$ & & & & & & \\
\hline Dicrurus paradiseus & Dicruridae & $\sqrt{ }$ & $\sqrt{ }$ & & & & & $\sqrt{ }$ & \\
\hline Megalaima australis & Capitonidae & & & $\sqrt{ }$ & $\sqrt{ }$ & & & & \\
\hline Megalaima mystacophanos & Capitonidae & & & $\sqrt{ }$ & $\sqrt{ }$ & & & & \\
\hline Tringa ochropu & Scolopacidae & & & & & $\sqrt{ }$ & & & \\
\hline Similarity index & & & & & & & & & \\
\hline
\end{tabular}


Oil palm plantation also brought about the effect on the evenness of butterfly and bird species. Although revealing variations, the evenness of butterfly species in all locations tended to decrease due to such oil-palm plantation establishment, as much as 7.69-11.45\% against the evenness value before the plantation existed, from a range of $0.91-0.98$ to $0.84-0.87$ (Figure 5). For birds, on the other hand, at two locations (BGA and AMR) there occurred a decrease in the evenness value as much as consecutively 3.33 and $16.65 \%$, while at the other two locations (GSIP and BLP) the evenness value tended to increase as much as $7.89 \%$ and $15.07 \%$, respectively (Figure 5).

This result differs from previous studies showing the number of species in oil palm plantations is lower than for secondary forest habitats. It probably due to habitat specification or a complex response of the butterfly (Ramos 2000; Koh 2007). The presence and the number of butterfly species are influenced by the intensity of sunlight and the tree canopy structure (Koh \& Sodhi 2004). Although belonging to the same age category, the age of oil palm trees observed and researched in this study is not the same as that in the Riau plantation. Different canopy structures will create variations in microclimate, crop diversity, food sources, and habitats in two locations. Also, Koh $(2007 ; 2008)$ asserted that the presence of butterflies is also determined by the presence of host trees that can serve as food crops. In this study, we found several plant species in oil palm plantations, which have potential as food sources; and consequently, attract butterflies to come, including Paspalum conjugatum, Ottochloa nodosa, Eleusine indica, Melastoma malabatricum, Ageratum conyzoides, and Clidemia hirta.

Impacts on the composition of species The butterflies at the three observed locations (BGS, AMR, and GSIP), tended to have the high index values which in a range from 0.72 to

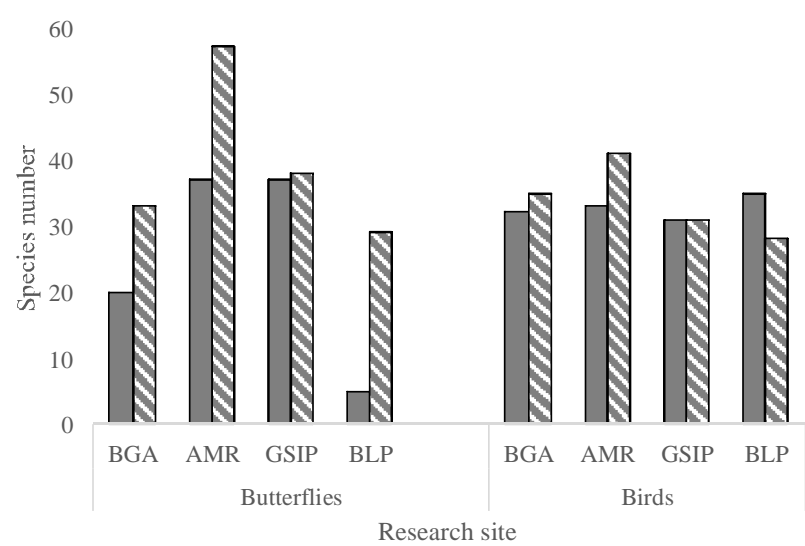

Figure 3 Richness of butterfly and bird species before the establishment of the oil-palm plantation and afterward. BGA, AMR, GSIP, BLP (four particular observed location at the research location); Margalef Index (Margalef's index of species diversity/richness); ( $\square$ ) the location as before the establishment of oil-palm plantation (BPE); ( $\square$ ) the location after the establishment of oil-palm plantation (APE); APE (the location after the establishment of oil-palm plantation).
0.83) (Table 1). These values were quite different from the similarity index value for the butterflies at BLP location (0.29), which was comparably much smaller. These phenomena could be brought about by changes in species composition, whereby several butterfly species were identified at habitat before the oil-palm plantation establishment; but no longer encountered afterward (lost). The reverse situation could also occur, whereby some butterfly species was found after the oil-palm plantation establishments, but never existed before; or some particular butterfly species could be found at those two habitats either before or after the plantation establishment. Entirely, after the establishment of the oil-palm plantation, all the observed locations sustained the addition of butterfly species which ranged from 7 to 24 species.

Based on other studies about other local/indigenous peo Conversely, the number of butterfly species that had lost was much smaller, which were consecutively one and six species at BGA and GSIP locations, respectively. Table 1 revealed that Nymphalidae family turned out to be the most dominant, indicating the high population at the research location as much almost $50 \%$ as of the overall butterfly species. These research results were similar to the results ever conducted in Central Kalimantan Province (Borneo), despite being carried out at the secondary forest and former rubber-tree plantation that was not precisely similar to the habitat in this research (Harmonis \& Saud 2017). Such high population of Nymphalidae family could be attributed to the needs of broad food variety and indicated a high abundance of food source in the location (Majumder et al. 2013; Widhiono 2015). In this research, it supported by the common encountering with the vegetation of Asteraceae, Poaceae, dan Melastomataceae families, which belonged the group of food sources for butterflies. Research results also revealed that changes in land cover did not bring about large impacts on the presence of several butterfly species such as Neptis hylas matula, Amathusia phidippus, Mycalesis horsfieldi (Nymphalidae); Eurema hecabe, and Leptosia nina (Pieridae), which could hold out in all locations at the habitats before as well as after

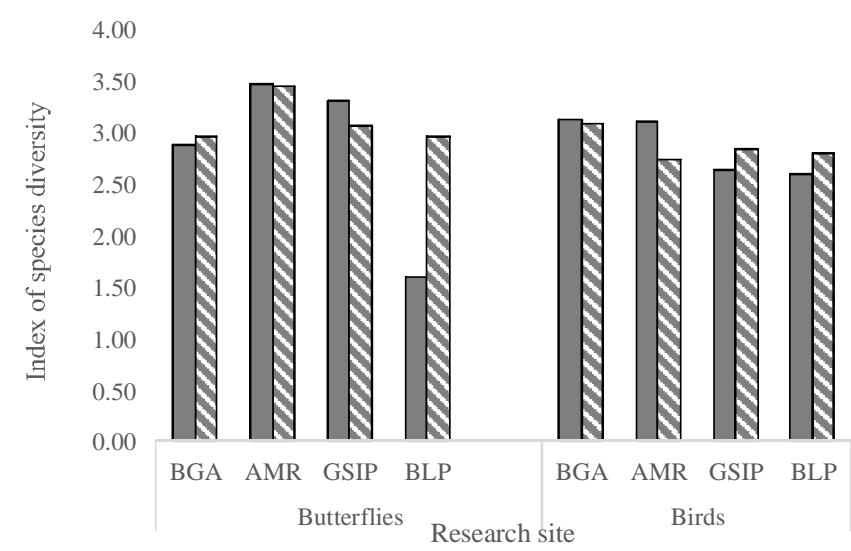

Figure 4 Diversity index for any of the butterfly and bird species. BGA, AMR, GSIP, BLP (four particular observed location at the research location); BPA ( $\square$ ) (the location as before the establishment of oilpalm plantation); SAP( $\square$ (the location after the establishment of oil-palm plantation). 


$$
1.2
$$

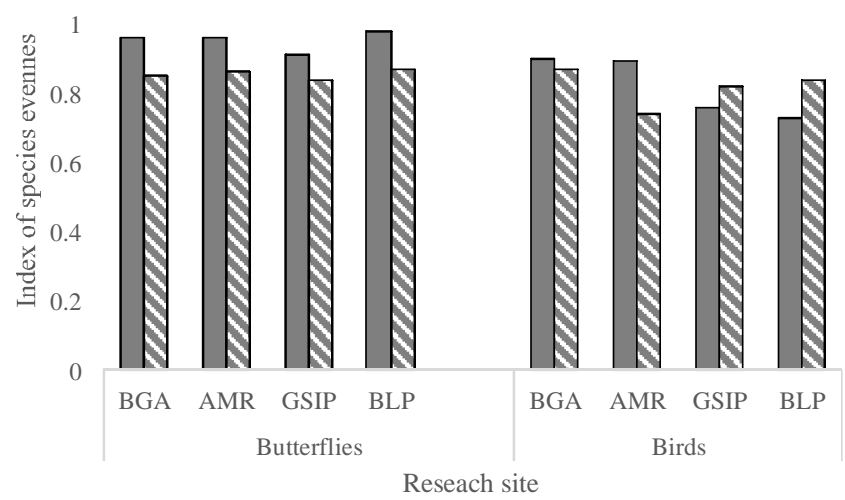

Figure 5 Evenness index for any of the butterfly and bird species. BGA, AMR, GSIP, BLP (four particular observed location at the research location); Evenness Index (index of species evenness); BPE $(\square)$ (the location as before the establishment of oilpalm plantation); APE ( $\square$ ) (the location after the establishment of oil-palm plantation).

the establishment of oil-palm plantation. These species belonged to the largest butterfly group in the world, which could be found in tropical forests, forest edge, and agriculture areas (Rusman et al. 2016; Harmonis 2017). Concerning birds, the values of species similarity index between BPE and APE condition at three observed locations (BGA, AMR, and GSIP) was quite high $(>0.8)$ as seen at Table 2. Reversely, the BLP location has the composition of bird species after the oil-palm plantation establishment which obviously differed from the composition before the plantation establishment. Such composition was notably changed due to the addition of particular bird species as many as seven until 14 species after the presence of oil-palm plantation; and concurrently, there e protected species in BPE habitats can still be found in the APE habitat, except Leptotilos javanicus found only in the area of BPE, while Psittacula longicauda located just in the $\mathrm{APE}$ area.

Overall, the Nectarinidae family represented the most dominant among other families; and they were more often encountered under the habitat condition after the plantation establishment (Table 2). Based on the kinds of food, it was also found Insectivores such as Prinia flaviventris, Meriops viridis, and Pycnonotus spp.; and birds that ate fruits and fruit seeds, such as Psittacula alexandri, P. longicauda, and Streptopelia chinensis. These insectivore birds may dominant at a particular type of habitat, such as mangrove (Hernowo 2016) and oil palm plantation, furthermore, could perform their role as natural pest control at the oil-palm plantation area (Koh 2008). These birds not only provide direct benefit to human but also could indirectly strengthen economy justification in the conservation of natural habitat and biodiversity at the landscape for agriculture as well as the plantation.

The composition of butterfly and bird species comprise of the species gain, species loss, and species persisted indicated a change in natural resources available in the forest and shrubs replace by oil palm plantation. This situation leads to species being lost due to changing the availability of resources, and to survive due to a wide spectrum of food sources and high adaptability (Edwards et al. 2013). In this way, therefore, changes in secondary forest and shrubs for conversion to the oil-palm plantation brought about impacts on increasing the number; and enhancing the presence of BPE several particular butterfly and bird species, especially for APE generalist species. However, Fermon et al. (2005) suggest that the increase in species richness does not necessarily indicate the high specificity of species so that the contribution of land use to global biodiversity should still be evaluated with caution.

Particular butterfly and bird species with special traits or which depended heavily on the presence of forests, they accordingly necessitated the heterogeneity of habitats, including the HCV forest to sustain the diversity of their species, which required specific ecology niches. Habitat heterogeneity at oil-palm plantation performed essential roles in conserving the biodiversity, and concurrently as the implementation to the environmental conveniences conforming to the consensus on Roundtable Sustainable Palm Oil (RSPO) dan Indonesian Sustainable Palm Oil (ISPO). Within this framework, oil palm plantations landscape with its forested area could be managed as a buffer system outside the conservation area, thus contributing to the conservation of biodiversity of certain species of birds and butterflies, as also proposed by Azhar et al. (2011) in the form of off-reserve management.

\section{Conclusion}

Oil-palm-plantation establishment that provided new habitat for particular butterfly and bird species, brought about significant ecological impacts on their species diversity and composition. In the new habitat, the number of butterfly and bird species tended to be greater than the number of their former habitat (secondary forest and shrubs). However, the diversity/richness, evenness, and similarity indices for those species (butterflies and birds) revealed variations. The oil-palm plantation landscape and reserved forest vegetation were essential in supporting diversity and ecological role of species on habitat condition after oil-palm plantation establishment.

\section{Acknowledgments}

The authors wish to express gratitude to the leaders and staffs of the oil-palm plantation companies owned by PT. BGA, PT. AMR, PT. GSIP, and PT. BLP, for permission, assistance, and facilities during the research activities performed in the field; to the local community who have allowed the authors to research their plantation

\section{References}

Atmowi, Buchori TD, Manuwoto S, Suryobroto B, Hidayat P. 2007. Diversity of pollinator insects in relation of seed set of Mustard (Brassica rapa L.: Cruciferae). Hayati Journal of Bioscience 14:155-161. https://doi.org/10.4308/hjb.14.4.155.

Azhar B, Chong LP, Zakaria M, Hassan N, Arif M. 2014. Effects of monoculture and polyculture practices in oil palm smallholdings on tropical farmland birds. Basic \& 
Applied Ecology 15:3 36-346. https://doi.org/10.1016/j.baae.2014.06.001.

[Dirjenbun]. Direktorat Jendral Perkebunan. 2016. Statistik Perkebunan Indonesia 2015-2017: Kelapa Sawit. http://ditjenbun.pertanian.go.id. [21 November 2017].

Dahelmi. 2000. Inventarisasi tumbuhan inang kupu-kupu Papilionidae di kawasan agar Alam Lembah Harau, Sumatera Barat. Jurnal Matematika IPA 9:19-21. http://repository.unand.ac.id/id/eprint/3534.

Edwards FA, Edwards, DP, Hamer, KC, Davies RG. 2013. Impacts of logging and conversion of rainforest to oil palm on the functional diversity of birds in Sundaland. The International Journal of Avian Science 155:313-326. http://onlinelibrary.wiley.com/doi/10.1111/ibi.12027

Erniwati, Zuhud EAM, Santosa Y, Anas I. 2016. The value of secondary forest patches for birds conservation in palm oil landscapes of Riau, Sumatera. Biodiversitas 17(2): 791-798. https://doi.org/10.13057/biodiv/d170256.

Febrita E, Yustina, Dahmania. 2014. Keanekaragaman jenis kupu-kupu (subordo rhopalocera) di kawasan wisata hapanasan rokan hulu sebagai sumber belajar pada konsep keanekaragaman hayati. Jurnal Biogenesis 10 (2): 48-58. https://ejournal.unri.ac.id/index.php/JPSB/article/view/19 13.

Fermon H, Waltert M, Vane-Wright RI, Mühlenberg M. 2005. Forest use and vertical stratification in fruit-feeding butterflies of Sulawesi, Indonesia: impacts for conservation. Biodiversity and Conservation, 12:1-18. https://link.springer.co/article/10.1007/s10531-004-53549

Fitzherbert EB, Struebig MJ, Morel A, Danielsen F, Brulh CA, Donald PA, Phalan B. 2008. How will oil palm expansion affect biodiversity?. Trends in Ecology and Evolution 23: $538-545$.

Hammond PC, Miller JC. 1998. Comparison of the biodiversity of Lepidoptera within three forested ecosystems. Annual of Entomology Society of America 91: 323-328. https://doi.org/10.1093/aesa/91.3.323.

Harmonis, Saud, OR. 2017. Effects of habitat degradation and fragmentation on butterfly biodiversity in West Kotawaringin, Central Kalimantan, Indonesia. Biodiversitas 18(2):500-506. https://doi.org/10.13 057/biodiv/d180208.

Hernowo JB. 2016. Birds communities at mangrove of Batu Ampar, Kubu Raya District, West Kalimantan Province. Jurnal Manajemen Hutan Tropika 22 (2):138-148. https://doi.org/ 0.7226/jtfm.22.2.138.

Info Sawit. 2017. Agustus, Ekspor Minyak Sawit Asal Indonesia Naik 24\%. http://www.infosawit.com/ newa/7082/agustus--ekspor-minyak-sawit--eksporminyak-sawit-asal-indonesia-naik-24-.[21 Nov 2017].
Koh LP. 2007. Impacts of land use change on South-east Asian forest butterflies: a review. Journal of Applied Ecology 44: $703-713$.https://doi.org/10.1111/j.13652664.2007.01324.x.

Koh LP. 2008a. Can oil palm plantations be made more hospitable for forest butterflies and birds?. Journal of Applied Ecology 45: 1002-1009. https://doi.org/10.1111/j.1365-2664.2008.01491.x

Koh LP. 2008b. Birds defend oil palms from herbivorous insects. Ecological Applications 18 (4):821-825. https://doi.org/ 10.1890/07-1650.1.

Koh LP, Sodhi NS. 2004. Importance of reverse, fragments, and parks for butterfly conservation in a tropical urban landscape. Ecological Applications 14 (6): 1695-1708.

Koh LP, Wilcove DS. 2007. Cashing in palm oil for conservation. Nature 448:993-994. http://www.nature.com/articles/448993a.

Koh LP, Wilcove DS. 2008. Is palm oil agriculture really destroying tropical biodiversity?. Conservations Letter 1: 60-64. https://doi.org/10.1111/j.1755263X.2008.00011.x.

Magurran A. 1988. Ecological Diversity and Its Measurement. London: Croom Helmed Limited

Majumder J, Lodh R, Agarwala BK. 2013. Butterfly species richness and diversity in the Trishna wildlife sanctuary in South Asia. Journal of Insect Science 13 (79). https://doi.org/ 10.1673/031.013.7901

Orians GH. 1969. The Number of Birds Species in Some Tropical Forest. New York (US): Saunders College.

Pascher K, Moser D, Sachslehner L, Hottinger H, Sauberer N, Dullinger S, Traxler A, Frank T. 2010. Field guide for a biodiversity inventory in the agrarian region Vascular plants, butterflies, grasshoppers and habitat structures. Vienna: University of Vienna.

Posha RMC, Sodhi NS. 2006. Effects of anthropogenic land use on forest birds and butterflies in Subic Bay, Philippines. Biological Conservation 129:256-270. https://doi.org/10.1016/j.biocon.2005.10.041.

Ramos FA. 2000. Nymphalid butterfly communities in an Amazonian forest fragment. Journal of Research on Lepidoptera 35:29-41. http://lepidopteraresearch foundation.org/pdf/pdf35/35-029.pdf.

Rusman RT, Atmowidi, Peggie D. 2016. Butterflies (Lepidoptera: Papilionoidea) of Mount Sago, West Sumatera: Diversity and flower preference. Hayati Journal of Bioscience 23:132-137. http://doi.org/101016/j.hjb.2016.12.001

Santosa Y, Sunkar A, Purnamasari I, Yohana. 2016. Sejarah Perkembangan Status, Penggunaan Lahan, dan 
Keanekaragaman Hayati Kebun Kelapa Sawit Indonesia. Laporan Hasil Penelitian. Badan Pengelola Dana Perkebunan Kelapa Sawit \& Lembaga Penelitian dan Pengabdian Kepada Masyarakat. Bogor.

Santosa Y, Purnamasari I, Wahyuni I. 2017. Perbandingan keanekaragaman kupu-kupu antara tipe tutupan lahan hutan dengan kebun sawit. In: Prosiding Seminar Nasional Masyarakat Biodiversitas Indonesia 3(1):104-109. http://doi.org/10.13057/psnmbi/m030119

Santosa Y, Purnamasari I. 2017. Variation of butterfly diversity in different ages palm oil plantation in Kampar, Riau. Prosiding Seminar Nasional Masyarakat Biodiversitas Indonesia 3(2):278-285. https://doi.org/10.13057/ psnmbi/m030220.

Santosa Y, Purnamasari I. 2017. Variation of butterfly diversity in different ages palm oil plantation in Kampar, Riau.
Prosiding Seminar Nasional Masyarakat Biodiversitas Indonesia 3(2):278-285. https://doi.org/ $10.13057 / \mathrm{psnmbi} / \mathrm{m} 030220$.

Smiley PC, Shields FD, Knight SS. 2009. Designing impact assessments for evaluating ecological effects of agricultural conservation practices on streams. Journal of The American Water Resources Association ( 45) 4: 867-878.

Terlizzi A, Scuderi D, Fraschetti S. Anderson MJ. 2005. Quantifying effects of pollution on biodiversity: a case study of highly diverse molluscan assemblages in the Mediterranean. Marine Biology (148): 293-305.

Widhiono I. 2015. Diversity of butterflies in four different forest types in Mount Slamet, Central Java, Indonesia. Biodiversitas 16 (2):196-204.ttps://doi.org/ 10.13057/biodiv/d160215. 